\title{
Comparison of Predicted Significant Coronary Lesion by Duke Treadmill Score among Coronary Heart Disease Risk Factors in Patients with Positive Ischemic Response Treadmill Test
}

\author{
David Rubiyaktho, Cholid Tri Tjahjono*
}

Division of Cardiac Rehabilitation and Prevention, Department of Cardiology and Vascular Medicine, Faculty of Medicine Universitas Brawijaya Malang- dr. Saiful Anwar Hospital Malang, Indonesia

\author{
Corresponding author : \\ Cholid Tri Tjahjono, MD, - email: cholidtt@gmail.com \\ Division of Cardiac Rehabilitation and Prevention, Department of Cardiology and Vascular Medicine, Faculty of Medicine \\ Universitas Brawijaya Malang- dr. Saiful Anwar Hospital Malang, Indonesia
}

Manuscript submitted: January 31, 2018; Revised and accepted: March 8, 2018

\section{ABSTRACT}

Background: According to Framingham Study, independent risk factors for coronary heart disease (CHD) are diabetes, hypertension, smoking, dyslipidemia, family history of CHD and obesity. Previous study reported cut-off value of Duke Treadmill Score (DTS) $<-0.5$ represents a significant coronary lesion with positive predictive value $88.4 \%$.

Objective: To compare the incidence of predicted significant coronary lesions by DTS among various risk factors for coronary heart disease.

Methods: A cross sectional study was done on 292 patients age 18 to 74 years old who had positive exercise testing for CAD screening during period of June $1^{\text {st }} 2016$ until May $30^{\text {th }} 2017$. DTS was calculated from treadmill test as: exercise time - $(5 \mathrm{x} \mathrm{ST}$ deviation in $\mathrm{mm})$ - (4 x exercise angina). A coronary lesion was predicted significant with DTS cut-off value $<-0.5$.

Results: Subjects mean age was 57 years old, male were $60.4 \%$. The risk factors for CHD were found sequentially from the most frequent were hypertension $51.9 \%$, smoking $35.3 \%$, diabetes mellitus $23.1 \%$, dyslipidemia $11.9 \%$, obesity $4.2 \%$ and family history of CHD $6.3 \%$. It was found that diabetes was significantly different from its effect on DTS value with $p$ value $=0.021$, while hypertension, obesity, dyslipidemia and family history CHD had no significant effect. Logistic regression found consistently that diabetes was significant $(p=0.019)$.

Conclusion: Predicted significant coronary lesions by DTS developed more frequent in diabetes compared to, hypertension, smoking, dyslipidemia, obesity and family history of coronary heart disease.

Keywords: risk factors; coronary heart disease; Duke Treadmill Score

\section{INTISARI}

Latar Belakang: Berdasarkan studi Framingham, faktor risiko independen dari penyakit jantung koroneradalah diabetes, hipertensi, dislipidemia, riwayat keluarga dengan penyakit jantung koroner, dan obesitas. Pada penelitian sebelumnya telah dilaporkan bahwa nilai batas dari Duke Treadimll Score (DTS) $<-0,5$ menggambarkan lesi koroner yang signifikan dengan nilai prediksi positif $88,4 \%$.

Tujuan: Membandingkan kejadian lesi koroner signifikan yang diprediksi dengan DTS pada berbagai faktor risiko penyakit jantung koroner.

Metode: Penelitian ini merupakan studi potong lintang yang dilakukan pada 292 pasien dengan rentang usia antara 18 sampai 74 tahun dengan hasil positif pada uji latih untuk deteksi dini CAD selama periode 1 Juni 2016 hingga 30 Mei 2017. DTS dihitung dari uji treadmill sebagai: waktu latihan - ( $5 x$ ST deviasi dalam $\mathrm{mm}$ ) - (4x angina selama latihan). Lesi koroner yang signifikan diprediksi dengan nilai batas DTS $<-0,5$. 
Hasil: Rata-rata usia subjek adalah 57 tahun, terdiri dari 60,4\% laki-laki. Faktor risiko CHD yang dijumpai secara berurutan dari yang paling sering adalah hipertensi $51,9 \%$, merokok $35,3 \%$, diabetes mellitus $23,1 \%$, dislipidemia $11,9 \%$, obesitas $4,2 . \%$, dan riwayat keluarga dengan CHD $6,3 \%$. Dijumpai perbedaan efek secara signifikan pada pasien dengan diabetes terhadap nilai DTS dengan $p=0,021$, sedangkan pada pasien dengan hipertensi, obesitas, dislipidemia, dan riwayat keluarga dengan CHD tidak ditemukan adanya efek yang signifikan. Regresi logistik juga menunjukkan hasil yang signifikan pada pasien dengan diabetes $(p=0,019)$.

Kesimpulan: Lesi koroner signifikan yang diprediksi dengan DTS lebih sering dijumpai pada pasien dengan diabetes dibandingkan pada pasien dengan hipertensi, merokok, dislipidemia, obesitas, dan riwayat keluarga dengan penyakit jantung koroner.

\section{INTRODUCTION}

Coronary artery disease is the leading cause of morbidity and mortality worldwide, and the incidence of coronary heart disease (CHD) has increased gradually. ${ }^{1}$ The cost of diagnostic and therapeutic interventions performed after clinical manifestations of CHD is substantially high. In the era of advanced cardiac imaging nowadays, East Java still does not have many facilities of MSCT, MRI or nuclear imaging. Therefore, it is important to combat risk factors prior to disease progression and to identify the presence of $\mathrm{CHD}$ by a simple and valid method before clinical signs of CHD appear.

Stratified risk during diagnostic and therapeutic CHD processes forms the basis of current guidelines. ${ }^{2}$ Risk assessment systems, such as the Framingham risk model, created using a variety of risk factors, are currently used to predict the risk of developing cardiovascular disease (CVD) or to determine treatment goals for prevention of disease progression. ${ }^{3}$ However, it is not used to predict the severity of $\mathrm{CHD}$ and plan for invasive and noninvasive diagnostic processes.

Duke treadmill score (DTS) has been shown to demonstrate the stratification of prognosis and has a good diagnostic value in predicting the number of coronary arteries involved in a patient population with ischemic heart disease. In addition, DTS has also been shown to have a strong correlation with the severity of coronary lesions assessed on the basis of the value of Syntax. ${ }^{4}$ DTS can estimate the presence and severity of CHD before coronary angiography and may be able to determine the method of revascularization required after the procedure. ${ }^{4}$ DTS has a sensitivity of $83.3 \%$ and a specificity of $71.5 \%$ in assessing future 30-day cardiovascular events, with a negative predictive value of $99.2 \%$ for the following 30 day free cardiovascular events. ${ }^{5}$ Gabaldo et al reported that all patients with high-risk DTS scores had significant coronary lesions or weight. Patients with moderate and mild-risk DTS scores obtained no significant coronary lesions in $50-90 \%$ of cases. High risk DTS scores indicate high potential for immediate coronary angiography. ${ }^{6}$

We aim to determine the differences of predicted significant coronary lesionby DTS among $\mathrm{CHD}$ risk factors in patients with positive ischemic response treadmill test.

\section{METHODS}

This study was designed as a crosssectional observational study. The sample was derived from treadmill registry of Dr. Saiful Anwar Hospital Malang, Indonesia of 905 consecutive patients underwent CAD screening. The study protocol was approved by the Local Ethics Committee (ethical clearance: no.400/184/K.3/302.2017).

The inclusion criteria were no history of prior CAD, admitted to the outpatient clinic with chest pain (typical angina, atypical angina, non-anginal chest pain) had a positive stress test and underwent coronary angiography 
(CAG) between June 2016 and May 2017. Patients with inadequate and negative ischemic response and age $>75$ years were excluded from the study. Patients with left bundle branch block, left ventricular hypertrophy, and WolffParkinson-White syndrome were not included in the study. ${ }^{7}$

Coronary risk factors were included such as hypertension, diabetes, smoker, dyslipidemia, obesity, and family history CAD which are modified risk factors that had been identified by referral cardiologist and or cardiologist in charge in treadmill test. For exercise treadmill testing, symptom-limited Bruce, modified Bruce and/or Naughton protocols were applied to all patients. Resting heart rate, blood pressure, and 12-lead ECG were recorded in the supine and upright positions before exercise. An ECG was repeated every 3 minute. Exercise testing was discontinued if exertional hypotension, malignant ventricular arrhythmias, marked ST depression ( $3 \mathrm{~mm}$ ), or limiting chest pain were observed. An abnormal exercise ST response was defined as $1 \mathrm{~mm}$ or more horizontal or downsloping ST depression (J point $\pm 60 \mathrm{~ms}$ ) or $1 \mathrm{~mm}$ or more ST-segment elevation in all leads excluding aVR without pathological $Q$ waves. ${ }^{7}$ The equation for calculating the Duke Treadmill Score (DTS) was as follows: DTS $=$ exercise time $-(5 \times$ ST deviation $)-$ $(4 \times$ exercise angina). Exercise angina was assessed as one of three levels: 0, none; 1 , non-limiting; and 2, exercise-limiting. The DTS typically ranges from -25 to $+15 .^{7}$

Coronary angiographies were performed in our hospital using the standard Judkins method with contrast agent manually delivered. Coronary angiograms were assessed independently by invasive cardiologists who were blinded to the clinical findings. Significant coronary lesion is an angiographic finding that is one or more coronary lesion met the criteria stenosis $\geq 50 \%$ at left main (LM), LAD stenosis in ostial / proximal $>50 \%$, LAD, mid-distal stenosis $>70 \%$, LCx stenosis $>70 \%$, and RCA stenosis $>70 \% .{ }^{8}$ In this study predicted significant coronary lesion was DTS value < -0.5 which were in accordance with in previous study. ${ }^{9}$

For statistics analysis, data was coded and analyzed using significant cut off value of $p \leq 0.05$. The category variable is expressed as number and percentage. Hypertension, diabetes, smoking, dyslipidemia and obesity were nominal variable. The DTS values associated with significant coronary lesion was nominal variables which were divided into less than < -0.5 (significant lesion) and $\geq-0.5$ (non significant lesion). The values of association between each $\mathrm{CHD}$ risk factors were analysed using chi square and logistic regression test on SPSS 24 software for windows.

\section{RESULTS}

During the study period, 905 patients were performed treadmill screened for suspected CHD. A total of 303 subjects gave a positive ischemic treadmill test result, 558 subjects had negative ischemic and 44 subjects had inadequate/inconclusive result. Based on further search, 105 subjects have been done coronary angiography.

Mean age of study subjects was 57 years with subject mostly male $(60.4 \%)$. The risk factors for $\mathrm{CHD}$ were found sequentially from the most frequent were hypertension 179 (51.9\%), smoking 107 (35.3\%), diabetes mellitus $70(23.1 \%)$, dyslipidemia $36(11.9 \%)$, obesity $43(4.2 \%)$ and family history of CHD $19(6.3 \%)$. The mean of BMI was $27.1 \mathrm{~kg} / \mathrm{m}^{2}$ and the fitness value was equivalent to 8.05 MET's. The average DTS was -3.79 . Clinical and demographic data of the research subjects are presented in table 1. 
Rubiyaktho et al., 2018

Table 1. Demographic and Clinical Characteristics of Research Subjects

\begin{tabular}{|c|c|c|c|c|}
\hline Characteristics & $\begin{array}{c}\text { DTS } \geq 5 \\
n=22 \\
(7.2 \%)\end{array}$ & $\begin{array}{c}\text { DTS 4-(-10) } \\
n=225 \\
(74.3 \%)\end{array}$ & $\begin{array}{c}\text { DTS } \leq-11 \\
n=56 \\
(18.5 \%)\end{array}$ & $P$ value \\
\hline Mean age(years) & 54.54 & 56.55 & 59.76 & 0.035 \\
\hline Mean BMI $\left(\mathrm{kg} / \mathrm{m}^{2}\right)$ & 27.03 & 27.15 & 26.91 & 0.916 \\
\hline Mean METs & 8.78 & 8.60 & 5.55 & 0.016 \\
\hline Mean DTS & 6.95 & -2.03 & -15.11 & 0.0001 \\
\hline Sex, $n(\%)$ & & & & 0.090 \\
\hline Man & $12(54.5 \%)$ & $130(57.8 \%)$ & $41(73.2 \%)$ & \\
\hline Woman & $10(45.5 \%)$ & $95(42.2 \%)$ & $15(26.8 \%)$ & \\
\hline \multicolumn{5}{|l|}{ Risk factors CAD, $\mathrm{n}(\%)$} \\
\hline Diabetes Melitus & $1(4.5 \%)$ & $54(24 \%)$ & $15(26.8 \%)$ & 0.091 \\
\hline Hypertension & $14(63.6 \%)$ & $136(60.4 \%)$ & $29(51.8 \%)$ & 0.451 \\
\hline Dyslipidemia & $3(13.6 \%)$ & $28(12.4 \%)$ & $5(8.9 \%)$ & 0.741 \\
\hline Smoker & $1(4.5 \%)$ & $25(11.1 \%)$ & $6(10.7 \%)$ & 0.715 \\
\hline Family history CAD & $1(4.5 \%)$ & $3(1.3 \%)$ & $1(1.7 \%)$ & 0.378 \\
\hline Obesity & $3(13.6 \%)$ & $33(5.8 \%)$ & $7(12.5 \%)$ & 0.914 \\
\hline Treadmill Protocol, n(\%) & & & & 0.010 \\
\hline Bruce & $12(54.5 \%)$ & $171(76 \%)$ & $35(62.5 \%)$ & \\
\hline Modified Bruce & $9(40.9 \%)$ & $52(23.1 \%)$ & $17(30.3 \%)$ & \\
\hline Naughton & $1(4.5 \%)$ & $2(0.9 \%)$ & $4(7.1 \%)$ & \\
\hline Number of coronary lesion, $n(\%)$ & & & & 0.066 \\
\hline Normal & $1(4.5 \%)$ & $6(2.7 \%)$ & $0(0 \%)$ & \\
\hline 1 Vessel disease & $0(0 \%)$ & $15(6.7 \%)$ & $0(0 \%)$ & \\
\hline 2 Vessel disease & $1(4.5 \%)$ & $17(7.5 \%)$ & $3(5.3 \%)$ & \\
\hline 3 Vessel disease & $3(13.6 \%)$ & $33(14.7 \%)$ & $19(33.9 \%)$ & \\
\hline 3 Vessel disease + left main & $0(0 \%)$ & $5(2.2 \%)$ & $2(3.6 \%)$ & \\
\hline Coronary lesion, $\mathrm{n}(\%)$ & & & & 0.078 \\
\hline Normal & $1(4.5 \%)$ & $6(2.7 \%)$ & $1(1.8 \%)$ & \\
\hline Nonsignificant & $4(18.2 \%)$ & $59(26.2 \%)$ & $24(42.8 \%)$ & \\
\hline Significant & $0(0 \%)$ & $11(4.9 \%)$ & $0(0 \%)$ & \\
\hline
\end{tabular}

Among patients proven to be ischemic positive response and coronary angiography results with significant lesions it was found that the youngest age was 43 years. The patient had a smoking risk factor and was able to achieve 10 METs. There most frequent performed treadmill with the Naughton treadmill protocol. Fewer patients performed Naughton protocol due to osteoarthritis and another elderly patient who is unable to walk on a treadmill machine with inclination. Nine patients were then excluded because they are more than 75 years old.

The DTS data was obtained as numerical variables, then a cut-off point determined from previous study in our data was -0.5 . We divided DTS group into $<-0.5$ as predicted significant lesion and $\geq-0.5$ as predicted nonsignificant lesion (Table 2).

A chi square test was conducted to analyze the influence of various risk factors of CHD on the DTS value that we divided into 2 groups, first was group with DTS value < -0.5 and second group with DTS value $>-0.5$. It was found that diabetes was significantly different from its effect on DTS value with $p$ value $=0.021$, while other $\mathrm{CHD}$ risk factors had no significant effect. Logistic regression was performed to analyse among all the CHD risk factors and found consistently that diabetes was the most influencel in the developing of predicted significant coronary lesion $(p=0.022$, $R R=2.017)$. The full results can be seen in table 3 below. 
Table 2. The DTS value of predicted significant coronary lesions

\begin{tabular}{lccc}
\hline \multicolumn{1}{c}{ CHD risk factors } & $\begin{array}{c}\text { DTS <-0.5 } \\
\mathrm{n}=\mathbf{1 7 9} \\
\mathbf{( 6 1 . 3 \% )}\end{array}$ & $\begin{array}{c}\text { DTS }>-\mathbf{0 . 5} \\
\mathrm{n}=\mathbf{1 1 3} \\
\mathbf{( 3 8 . 7 \% )}\end{array}$ & P value \\
\hline Hypertension, $\mathrm{n}(\%)$ & $106(59.2 \%)$ & $67(59.3 \%)$ & 0.940 \\
Diabetes, $\mathrm{n}(\%)$ & $51(28.5 \%)$ & $19(16.8 \%)$ & 0.021 \\
Dyslipidemia, $\mathrm{n}(\%)$ & $17(9.5 \%)$ & $19(16.8 \%)$ & 0.068 \\
Smoking, $\mathrm{n}(\%)$ & $63(35.2 \%)$ & $42(37.1 \%)$ & 0.774 \\
Family history CAD, $\mathrm{n}(\%)$ & $13(7.3 \%)$ & $6(5.3 \%)$ & 0.498 \\
Obesity, $\mathrm{n}(\%)$ & $27(15.1 \%)$ & $14(12.4 \%)$ & 0.500 \\
\hline
\end{tabular}

Table 3. Logistic regression analysis of influence of CHD risk factors to DTS

\begin{tabular}{lcccc}
\hline \multirow{2}{*}{ Risk factors } & \multirow{2}{*}{ RR } & \multirow{2}{*}{ P value } & \multicolumn{2}{c}{ 95\% CI RR } \\
& & & Lower & Upper \\
\hline Hypertension & 1.045 & 0.865 & 0.629 & 1.736 \\
Smoking & 0.978 & 0.931 & 0.589 & 1.624 \\
Obesity & 1.313 & 0.456 & 0.642 & 2.688 \\
Dyslipidemia & 0.502 & 0.061 & 0.244 & 1.032 \\
Family history CAD & 1.758 & 0.292 & 0.616 & 5.018 \\
Diabetes & 2.017 & 0.022 & 1.106 & 3.677 \\
\hline
\end{tabular}

\section{DISCUSSION}

During the period from June 1, 2016 to May 30,2017 , there were 303 (33.4\%) patients with positive ischemic response out of a total of 905 patients performed by treadmill. It means that in one year of outpatient population of heart disease in our hospital potentially get 905 patients of new CHD screening. Only one-third of those sent for CHD screening are proven to be ischemic. This could be our reminder to further apply pre-test probabilities before sending patients to exercise test.

Characteristics of research subjects from this study obtained the average age of the subject are 57 years. Based on the RISKESDAS data of 2013, the prevalence of coronary heart disease in Indonesia based on interviews conducted by doctors or those diagnosed by doctors from clinical symptoms increases with age.$^{10}$ The highest prevalence was found in the $65-74$ years age group of $2.0 \%$ and $3.6 \%$ and then slightly decreased in the age group $\geq 75$ years. Meanwhile, data from the United States for a population of 60-79 years, estimated the prevalence rate of $23 \%$ of men and $15 \%$ of women are increasing at age $>80$ years, i.e. $33 \%$ in men and $22 \%$ in women. ${ }^{11}$ This study proves that patients with $\mathrm{CHD}$ are majority males. It is as previously reported that women are less populated than men and the age of $\mathrm{CHD}$ patients in women is 10-15 years older than men. ${ }^{11}$

Previous data showed that the prevalence of patients with $\mathrm{CHD}$ increases in the population $>60$ years, both in Indonesia and the United States. In this study, obtained mean age older than previous report, with the youngest age subject is 43 years..$^{13}$ This suggests that the incidence of cardiovascular disease is more prone to occur at a younger age, related to the unhealthy lifestyles of today, such as sedentary life-style, high fat and salt dietary intake, as well as stressful life situations. Demographic differences can make a difference in age findings where in previous studies in Jakarta the average age was found to be younger and more women and from our data showed that CHD appeared at older and more male.

Cardiovascular risk factors in this study subjects were most commonly found hypertension 179 (51.9\%), smoking 107 (35.3\%), 
diabetes mellitus 70 (23.1\%), dyslipidemia 36 $(11.9 \%)$, obesity $43(4.2 \%)$ and family history of CHD 19 (6.3\%). Zhang et al. (2014) reported that hypertension and diabetes had a strong predictor of atherosclerotic development. ${ }^{14} \mathrm{~A}$ study in Korea reported that hypertension was one of the independent predictors of significant coronary stenosis in subjects with heavy ST-segment depression ( $\geq 2 \mathrm{~mm}$ ) of the treadmill test. ${ }^{15}$ Other study found that in the subjects with hypertension, hyperglycaemia and hyperglycaemia risk factors in both men and women were $30.1 \%$ and $24.8 \%$, respectively; $64 \%$ and $67.4 \%$; and $26.7 \%$ and $23.6 \% .{ }^{16}$ Based on these data, hypertension and diabetes are important risk factors for the incidence of cardiovascular disease, although other risk factors such as dyslipidemia, obesity, and family history of heart disease cannot be ignored.

Smoking as a risk factor for $\mathrm{CHD}$ has also been widely demonstrated because it is associated with the effects of endothelial dysfunction. Some studies suggest that smoking increases the risk of $\mathrm{CHD}$ by 1.66 times in those who smoked cigarettes $<14$ cigarettes a day and the risk increased almost twice in numbers over 15 cigarettes. ${ }^{17,18}$ Hassan et al.(2014) compared the $\mathrm{CHD}$ risk factors with angiographic characteristics coronary and found that at the young age ( $<45$ years) as much as $78 \%$ of subjects were smokers. ${ }^{19}$ This is consistent with our findings that the youngest patients with significant coronary lesions aged 43 years and risk factors for smokers.

Diabetes mellitus as a risk factor that is equivalent to coronary heart disease needs special attention. Patients with diabetes tend to have a higher incidence of silent ischemia compared with non-diabetics. ${ }^{20}$ From a study conducted by Martin-Timon et al.(2014) reported that diabetes has a strong association with other traditional factors that allow a strong predictor of atherosclerotic development. ${ }^{17}$ Other studies have also shown that diabetes is significantly correlated with the formation of significant coronary lesions and the number of blood vessels involved. ${ }^{21}$

A total of 292 suspected CHD patients with positive ischemic results with treadmill, and 179 subjects or $61.3 \%$ is predicted to have significant coronary lesion therefore they should be sent to the catheter laboratory (cathlab) as soon as possible. Indeed in this study we did not explore the reasons why only a third of patients with positive ischemic evidence but further data remind us in optimizing the cathlab as a main of diagnosis and treatment of CHD. This is where we consider it necessary to pay more attention to the treadmill results that are currently our main modality in our hospital as a means of finding ischemic evidence in suspected CHD patients especially in diabetes patients. Furthermore, which revascularization strategy is used can not only be determined at DTS values but still consider at coronary angiography results and other clinical conditions. ${ }^{22}$

The limitations of the study of our study should be declared. Our study design was cross-sectional. We realize that this study was still not perfect where the weakness was still a retrospective study with medical record data which of course we could not control the confounding factor and its bias. The identification of $\mathrm{CHD}$ risk factors was generally from referral cardiologist and partly from cardiologist in charge. In the measurement of the DTS value component the researcher could not ascertain uniformity in the assessment of angina because the operator accompanying the examiner was differrent over that period. The study sample was not taken randomly because of the limitations of patients who had fulfilled the inclusion requirements, especially those patients who had undergone coronary angiography. Further studies with larger patient populations and cohort are suggested. 


\section{CONCLUSIONS}

Predicted significant coronary lesions by DTS developed more frequent in diabetes compared to, hypertension, smoking, dyslipidemia, obesity and family history of coronary heart disease.

\section{Conflict of interest: none declared}

\section{REFERENCES}

1. Murray C.J., Lopez A.D., 1997. Global mortality, disability, and the contribution of risk factors: Global Burden of Disease Study. Lancet, 349:1436-1442.

2. Graham I., Atar D., Borch-Johnsen K., Boysen G., Burell G., Cifkova R., et al. 2007. European guidelines on cardiovascular disease prevention in clinical practice: executive summary: fourth joint task force of the European society of cardiology and other societies on cardiovascular disease prevention in clinical practice. Eur Heart $\mathrm{J}$, 28:2375-2414.

3. Wilson P.W., D'Agostino R.B., Levy D., Belanger A.M., Silbershatz H., Kannel W.B. 1998. Prediction of coronary heart disease using risk factor categories. Circulation, 97:1837-1847.

4. Günaydın Z.Y., Bektaş O., Gürel Y.E., Karagöz A., Kaya A., KırışT., et al. 2016. The value of the Duke treadmill score in predicting the presence and severity of coronary artery disease. KardiologiaPolska, 74:127-134.

5. Manini A.F., McAfee A.T., Noble V.E., Bohan J.S. 2010. Prognostic value of the Duke Treadmill Score for Emergency Departementpatients with chest pain. J Emerg Med, 39:135-143.

6. Gabaldo K., Hadzibegović I., Prvulović D., Vujeva B., Samardzić P., Danić D. 2008. Duke Treadmill Score in prioritizing patients for coronary angiography: retrospective study of a Croatian regional hospital.Coll. Antropol,32: 375-380.

7. Radi B., Arso I.A., Sarvasti, D., Tadjoedin Y., Tjahjono C.T. 2016. Pedoman Uji Latih Jantung, edisi pertama. PERKI, Jakarta, Indonesia.

8. Firdaus I., Rahajoe A.U., Yahya A.F., Lukito A.A., Kuncoro A.S., Lilyasari O., et al. 2016. Panduan Praktik Klinis (PPK) dan Clinical Pathway (CP) Penyakit Jantung dan Pembuluh Darah. PERKI, Jakarta, Indonesia.

9. Rubiyaktho D., Martini H, Satrijo B. 2017. Skor Duke Treadmill sebagai Prediktor Lesi Koroner Signifikan pada Pasien Respon Iskemik Positif Uji Latih Jantung. Malang, Indonesia.

10. Kementrian Kesehatan RI, Riskesdas, 2013. Jakarta, Indonesia

11. Fihn S., Gardin J., Abrams J., Berra K., Blankenship J., Dallas A., et al. 2012. AHA Guideline for the diagnosis and management of patients with stable ischemic heart disease. Circulation, 126:3097-3137.

12. Yahagi K., Davis H.R., Arbustini E., Virmani R. 2015. Sex differences in coronary artery disease: Pathological observations. Atherosclerosis, 239:260-267.

13. Ikhsan M., Nasution S.A., Wijaya I.P., Rumende C.M. 2016. Peran Duke treadmill score sebagai predictor penyakit jantung koroner pada pasien dengan uji treadmill positif. Jurnal Penyakit Dalam Indonesia, 3:81-87.

14. Zhang J.X., Dong H.Z., Chen B.W., Cong H.L., Xu J. 2016. Characteristics of coronary arterial lesions in patients with coronary heart disease and hypertension. Springer Plus, 5:1208.

15. Cha K.S. 2012. The exercise treadmill test:predictors of true presence of significant coronary stenosis in patients with severe 
ST-segment depression. Acta Cardiol, 67:297-302.

16. Yang Z.J., Liu J., Ge J.P., Chen L., Zhao Z.G., Yang W.Y. 2012. Prevalence of cardiovascular disease risk factor in the Chinese population: the 2007-2008 China National Diabetes and Metabolic Disorders Study. Eur Heart J, 33:213-220.

17. Martín-Timón I., Sevillano-Collantes C., Segura-Galindo A., delCañizoGómez F.J. 2014. Type 2 diabetes and cardiovasculardisease: Have all risk factors the same strength? World J Diabetes, 5: 444-470.

18. Chaturvedi N., Stevens L., Fuller J.H. 1997. Which features of smokingdetermine mortality risk in former cigarette smokerswith diabetes? The World Health Organization MultinationalStudy Group. Diabetes Care, 20:1266-1272.

19. Hassan Z., Farooq S., Nazir N., Iqbal K. 2014. Coronary artery disease in young : A study of risk factors and catheterization in the valley of Kashmir. International Journal of Scientific and Research Publications, 4:1-7.

20. Bourque J.M., Beller G.A. 2015. Value of exercise ECG for risk stratification in suspected or known CAD in the era of advanced imaging technologies. JACC Cardiovasc Imaging, 8:1309-1321.

21. Bittencourt C., Piveta V.M., Oliveira C.S., Crispim F., Meira D., Saddi-Rosa P., et al. 2014. Association of classical risk factors and coronary artery disease in type 2 diabetic patients submitted to coronary angiography. Diabetol Metab Syndrome, 6:46.

22. Dzenkeviciute V., Sapoka V., Kasiulevicius V., Rinkuniene E., Steponeniene R., Einikyte R., et al. 2017. Value of Duke treadmill score in predicting coronary artery lesion and the need for revascularisation. Kardiologia Polska, 75:439-444. 